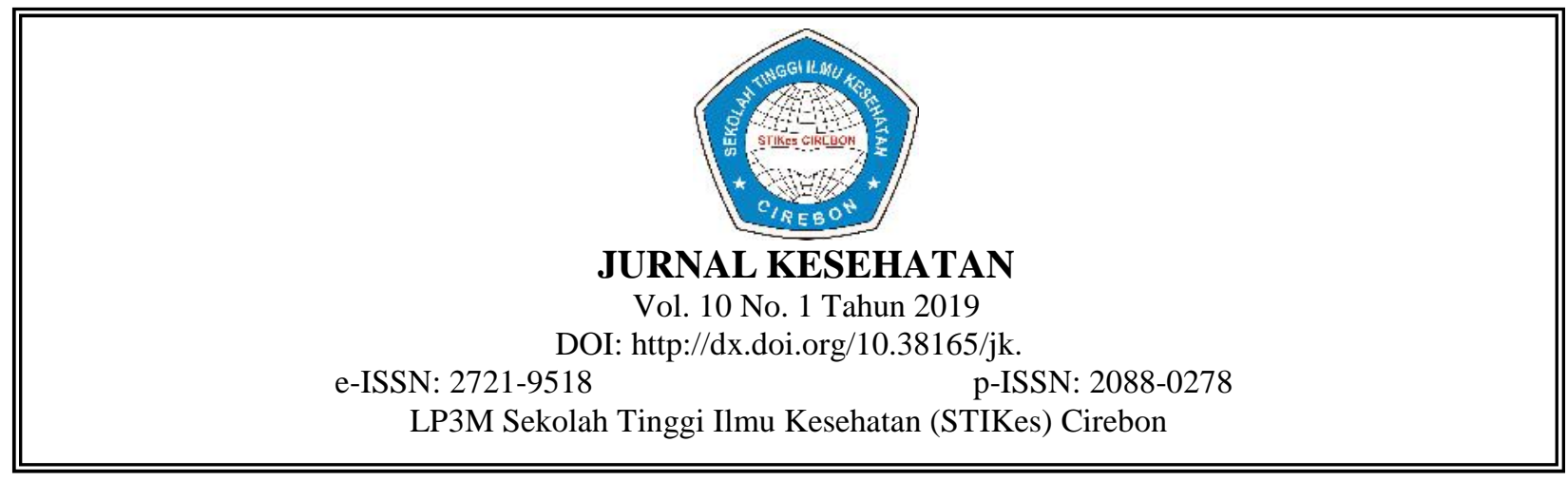

\title{
LIMA FAKTOR YANG MEMPENGARUHI KESEJAHTERAAN IBU DAN ANAK PASCA MELAHIRKAN
}

\author{
Yosi Yusrotul Khasanah* \\ Program Studi Kebidanan Sekolah Tinggi Ilmu Kesehatan Cirebon \\ yosikhasanah84@yahoo.com
}

\begin{abstract}
Abstrak
Kesehatan ibu dan anak dalam keluarga merupakan salah satu indikator kesejahteraan ibu dan anak. Keberhasilan upaya kesejahteraan dan kesehatan ibu diantaranya dapat dilihat dari Angka Kematian Ibu (AKI). Penurunan AKI di Indonesia terjadi peningkatan di 2012 menjadi 359. Tujuan penelitian ini adalah mengetahui pengaruh peran tenaga kesehatan, keterpaparan informasi, ketahanan komunitas, ketahanan keluarga, dan ketahanan individu terhadap kesejahteraan ibu dan anak pasca melahirkan di wilayah Kabupaten Cirebon. Metode yang digunakan dalam penelitian ini adalah pendekatan kuantitatif yang menggunakan desain cross-sectional (potong lintang). Populasi adalah ibu-ibu yang menyusi bayi sejumlah 120 dan sampel yang digunakan sebanyak 90 ibu menyusui. Metode analisis yang digunakan adalah Structural Equation Model (SEM) mengunakan SmartPLS 2.0 dan SPSS 20. Pengumpulan data menggunakan metode angket. Instrumen data menggunakan kuesioner. Hasil penelitian menunjukkan pengaruh yang paling besar terhadap kesejahteraan ibu dan anak pasca melahirkan di wilayah Kabupaten Cirebon adalah tenaga kesehatan $(23,82 \%)$, peran tenaga kesehatan sebagai motivator ini bermakna dorongan terhadap serangkaian proses perilaku manusia pada pencapaian tujuan.
\end{abstract}

Kata Kunci: Tenaga Kesehatan, Informasi, Komunitas, Individu, Kesejahteraan ibu dan anak

\begin{abstract}
Maternal and child health in the family is one indicator of the welfare of mother and children. The success of maternal welfare nd health effort can be seen from the maternal mortality rate.the decline in maternal mortality in Indonesia has increased 2012 to 359. The purpose of this study was determine the effect and magnitude between health worker. Information explosive, community resilience, family resilience, family resilience and individual resilience to post partum wellfare for mother and children in the Cirebon district. The methode used in this study is a quantitave approach that uses a cross sectional desain (cross secsional). The analytical methode used is a structural equation model (SEM) using smart pls 2.0 and SPSS2.0 Data collection uses the questionnaire method. Data instruments using questionnaires. The results showed that the greatest influence on the wellfare of postpartum mothers and children in the Cirebon regency is health workers $(23,82 \%)$. The role of health worker as motivator means encaouging a series of proceses of human behavior towards archeiving goals.
\end{abstract}

Keywords: Medical Staff, Information, Comunity, Individual, Mother and Child Welfare 


\section{PENDAHULUAN}

Perkembangan kependudukan dan pembangunan keluarga yang tertera dalam Undangundang nomor 52 tahun 2009, mendefinisikan keluarga adalah sebagai unit terkecil dalam masyarakat yang terdiri dari suami istri, suami istri dan anak, atau ayah dan anaknya, atau ibu dan anaknya. Sebuah keluarga terdapat dua atau lebih yang terjadi dari sebuah pribadi yang tergabung karena hubungan darah, hubungan perkawinan atau pengangkatan dihidupnya dalam satu rumah tangga, terdapat interaksi satu sama lain dan mempunyai peran masing-masing untuk menciptakan dan mempertahankan sebuah kebudayaan. ${ }^{1}$

Keberhasilan upaya kesejahteraan dan kesehatan ibu diantaranya dapat dilihat dari indikator angka kematian ibu (AKI). AKI merupakan jumlah kematian ibu selama masa kehamilan, persalinan, dan nifas yang disebabkan oleh proses kehamilan, persalinan, dan nifas atau pengelolaanya tetapi bukan karena sebab-sebab lain seperti terjadi kecelakaan, terjatuh dan atau kejadian yang tidak ada kaitanya dengan kondisi masa kehamilan dan sampai pada nifas disetiap 100.000 kelahiran hidup. Penurunan AKI di Indonesia terjadi sejak tahun1991 sampai dengan 2007, yaitu dari 390 menjadi 228. Salah satu sasaran yang ditetapkan untuk tahun 2010 adalah menurunkan angka kematian ibu menjadi 125 per 100.000 kelahiran hidup, dan angka kematian neonatal 16 per 1000 kelahiran hidup. Namun sampai saat ini sasaran tersebut belum tercapa. ${ }^{2}$

Peraturan Pemerintah Republik Indonesia Nomor 87 Tahun 2014 tentang perkembangan kependudukan dan perkembangan keluarga, keluarga berencana, dan sistem informasi keluarga, menyebutkan bahwa pembangunan sebuah keluarga dilakukan dalam upaya untuk mewujudkan keluarga yang hidup berkualitas dalam lingkungan yang sehat. Disamping itu kondisi kesehatan dari stiap pribadi anggota keluarga sendiri juga merupakan sebagai salah satu syarat dari sebuah keluarga yang berkualitas. ${ }^{3}$

Sebagai upaya untuk penurunan AKI, melalui Kementerian Kesehatan, pemerintah telah meluncurkan program Kesehatan Ibu dan Anak (KIA), yakni sebuah program yang mengupayakan kesehatan ibu dan anak yang menyangkut pelayanan dan pemeliharaan ibu hamil, ibu bersalin, ibu menyusui, bayi dan anak balita serta anak prasekolah. Berdasarkan pengertian tersebut, program KIA diarahkan pada kesehatan ibu dan anak, program yang menyangkut kesehatan ibu terbagi dalam tiga bagian yaitu perawatan ante partum (waktu hamil), perawatan intra partum (waktu melahirkan) dan post partum (pasca melahirkan). ${ }^{4}$

Keluarga sejahtera merupakan keluarga yang dibentuk berdasarkan atas perkawinan yang sah, mampu memenuhi kebutuhan hidup spiritual dan material yang layak, bertakwa kepada Tuhan Yang Maha Esa, memiliki hubungan yang serasi, selaras dan seimbang antar anggota keluarga dan antara keluarga dengan masyarakat dan lingkungan. ${ }^{5}$ Salah satu unsur ketahanan komunitas adalah pemberdayaan masyarakat yang merupakan upaya memfasilitasi masyarakat untuk membangun sistem kesiagaan dalam upaya mengatasi situasi gawat darurat dari aspek non klinis terkait kehamilan dan persalinan. Sistem kesiagaan merupakan sistem tolong-menolong, yang dibentuk dari, oleh dan untuk masyarakat, dalam hal penggunaan alat transportasi/komunikasi (telepon genggam, telpon rumah), pendanaan, pendonor darah, pencatatan-pemantauan dan informasi KB. Dalam pengertian ini tercakup pula pendidikan kesehatan kepada masyarakat, pemuka masyarakat, pemuka masyarakat serta menambah keterampilan para dukun bayi serta pembinaan kesehatan akan di taman kanak-kanak. ${ }^{6}$

Ketahanan individu adalah salah satu faktor pendukung utama dalam unsur-unsur pembentuk ketahanan komunitas. ${ }^{7}$ Kematian ibu saat melahirkan diakibatkan dua penyebab yakni penyebab langsung dan tidak langsung. Penyebab tidak langsung dibagi dua yaitu 3T dan 4T, untuk penyebab $3 \mathrm{~T}$ meliputi terlambat ditemukan kasus-kasus resikonya, terlambat dirujuk dan terlambat ditangani. Sedangkan untuk 4T karena terlalu muda hamil, terlalu banyak punya anak, terlalu tua ibu hamil dan terlalu rapat anaknya. Sedangkan untuk penyebab langsung bisa diakibatkan pendarahan saat melahirkan, kejang-kejang karena ada kenaikan tekanan darah atau sering disebut eklamsia. Dan ada juga penyebab-penyebab lain ibu meninggal saat melahirkan seperti infeksi, DHF, jantung, TBC dan lainnya. ${ }^{8}$ Dinas Kesehatan Kabupaten Cirebon terus 
berupaya menekan Angka Kematian Ibu (AKI) saat persalinan, dengan meningkatkan Sumber Daya Manusia (SDM) bidan desa dan peningkatan infrastuktur Puskesmas Poned. Di tahun 2014 ibu melahirkan hidup tercatat sebanyak 47.738 orang dan di tahun 2015 menurun menjadi 47.600an. Dengan jumlah kematian ibu pada tahun 2014 tercatat 49 orang dan 53 ibu pada tahun 2015 . Sedangkan kematian bayi tahun 2014 ada 206 dan ditahun 2015 ada 210 bayi baru lahir hingga bayi usia 42 hari. ${ }^{9}$

Permasalahan yang dihadapi ibu dan anak pasca melahirkan sangat komplek. Berbagai upaya dilakukan untuk meminimalisir permasalahan yang dihadapi telah dilakukan, diantaranya mengoptimalkan peran tenaga kesehatan dan keterpaparan informasi yang lebih tepat dan akurat agar mudah dijangkau oleh semuanya. Ketahanan komunitas yang merupakan pemberdayaan masyarakat dalam upaya memfasilitasi masyarakat untuk membangun sistem kesiagaan untuk mengatasi situasi gawat darurat dari aspek non klinis terkait kehamilan dan persalinan juga sangat diperlukan. Sisi lain yang tidak kalah penting adalah ketahanan keluarga karena keluarga merupakan unit dasar masyarakat yang berperan penting dalam menghasilkan SDM yang berkualitas untuk keberlangsungan masyarakat. Kegagalan/ketidakberfungsian keluarga dapat menimbulkan berbagai implikasi sosial, ekonomi, dan sebagainya.

Penelitian terkait kesejahteraan ibu dan anak pasca melahirkan belum banyak dilakukan, terlebih penelitian yang dilakukan di Kabupaten Cirebon, belum pernah dilakukan. Berbeda dengan penelitian tentang peran tenaga kesehatan sudah banyak dilakukan. Kabupaten Cirebon di tahun 2014 ibu melahirkan hidup tercatat sebanyak 47.738 orang dan di tahun 2015 menurun menjadi 47.600-an. Dengan jumlah kematian ibu pada tahun 2014 tercatat 49 orang dan 53 ibu pada tahun 2015. Sedangkan kematian bayi tahun 2014 ada 206 dan ditahun 2015 ada 210 bayi baru lahir hingga bayi usia 42 hari. ${ }^{10}$ Tujuan penelitian ini adalah mengetahui pengaruh peran tenaga kesehatan, keterpaparan informasi, ketahanan komunitas, ketahanan keluarga, dan ketahanan individu terhadap kesejahteraan ibu dan anak pasca melahirkan di wilayah Kabupaten CirebonTahun 2018”.

\section{METODE PENELITIAN}

Jenis penelitian ini menggunakan metode deskriptif analitik, dengan desain penelitian potong lintang (cross sectional). Penelitian ini dilaksanakan di Kabupaten Cirebon. Waktu penelitian pada Agustus-September 2018. Populasi dalam penelitian ini ibu menyusui di Asosiasi ibu menyusui yang ada di Kabupaten Cirebon. Bulan Agustus - September 2018 berjumlah 200 orang. Sampel penelitian ini adalah ibu menyusui di organisasi Assosiassi Ibu Menyusui Indonesia (AIMI) di Kabupaten Cirebon. dalam hal ini peneliti ambil 90 ibu menyusui di AIMI sebagai sampel.

Kriteria Inklusi adalah ibu menyusui secara eksklusif yang ada di Kabupaten Cirebon, dan ibu menyusui yang bersedia menjadi responden. Teknik pengambilan sampel penelitian menggunakan purposive sampling yaitu didasarkan pada suatu pertimbangan tertentu yang dibuat oleh peneliti sendiri, berdasarkan ciri atau sifat-sifat populasi yang sudah diketahui sebelumnya. ${ }^{11}$ Pengumpulan data dalam penelitian dilakukan melalui penyebaran kuesioner berskala sematic differential yang berisi pernyataan mengenai variabel eksogen dengan pengukuran penelitian menggunakan pengukuran sematic differential dengan jawaban sangat positif terletak di bagian kanan yang memiliki nilai 5 dan jawaban yang sangat negatif terletak di bagian kiri dengan nilai pernyataan instrumen penelitian akan dilakukan uji validitas yang bertujuan untuk mengetahui validitas kuesioner dengan membandingkan nilai $r$ tabel dan $r$ hitung pada tingkat kemaknaan 5\% $(0,05)$.

Analisis data dalam penelitian menggunakan analisis Structural Equation Model (SEM) dengan Partial Least Square (PLS). Langkahnya dengan menganalisis data penelitian menggunakan rancangan model pengukuran (Outer Model) atau uji indikator. Uji Outer Model ini digunakan untuk mendefisikan bagaimana setiap blok indikator berhubungan dengan variabel latennya dengan mengevaluasi melalui Converegent Validity yaitu nilai loading faktor penelitian telah memenuhi 
syarat lebih besar dari 0,5. Evaluasi Discriminant Validity dengan nilai korelasi Cross Loading terhadap variabel latennya harus lebih besar dibandingkan dengan korelasi terhadap variabel laten lainnya. Evaluasi Avarage Variance Extracted (AVE) untuk melihat validitas variabel yang akan diteliti, dengan syarat nilai Avarage Variance Extracted $>0,05$ setelah diuji validitas dan dinyatakan variabel serta indikator telah valid, maka dilakukan uji reliabilitas dengan mengevaluasi nilai Cronbach's Alpha dan Composite Reability harus > 0,70.

Setelah uji Outer Model (uji indikator) sesuai dengan kriteria maka dilakukan uji Inner Model atau uji hipotesis dengan mengambarkan hubungan antar variabel laten berdasarkan pada substantive theory dengan hasil $\mathrm{R}^{2}$ untuk variabel laten endogen sebesar 0,67 model dikatakan baik, sebesar 0,33 model dikatakan moderat dan 0,19 model penelitian dikatan lemah. Uji hipotesis juga dilihat dari nilai koefisien parameter dan $\mathrm{T}$ statistik untuk melihat uji hipotesis terhadap indikator dari variabel yang diteliti. Nilai estimasi untuk hubungan jalur dalam model konstruk harus signifikan $(>1,96)$ yang dapat diperoleh melalui prosedur bootsrapping.

\section{HASIL PENELITIAN \\ Karakteristik Responden}

Responden dalam kelompok usia 21 - 30 tahun, yaitu sebanyak 56 orang $(62,2 \%)$, kemudian umur 31-40 tahun sebanyak 34 orang (37,8\%). Responden yang bekerja sebanyak 30 orang $(33,3 \%)$, kemudian responden yang tidak bekerja sebanyak 60 orang $(66,7 \%)$ atau sebagian besar responden tidak bekerja.

\section{Variabel penelitian}

Table 1. Hasil analisis univariat

\begin{tabular}{lcccc}
\hline Variable Penelitian & Rata-rata & Standar Deviasi & Minimum & Maksimum \\
\hline Kesejahteraan & 62,50 & 9,20 & 33 & 74 \\
Tenaga Kesehatan & 59,19 & 12,04 & 34 & 75 \\
Keterpaparan Informasi & 62,07 & 10,86 & 32 & 73 \\
Ketahanan komunitas & 61,36 & 10,52 & 33 & 74 \\
Ketahanan Keluarga & 61,90 & 8,66 & 32 & 73 \\
Ketahanan Individu & 60,23 & 9,96 & 34 & 75 \\
\hline
\end{tabular}

Variabel kesejahteraan ibu dan anak didapatkan hasil nilai rata-rata 62,50, standar deviasi 9,20 nilai minimum 33 dan nilai maksimum 74, untuk variabel tenaga kesehatan didapatkan nilai rata-rata 59,19, standar deviasi 12,04 nilai minimum 34 dan nilai maksimum 75 , untuk variabel keterpaparan informasi didapatkan hasil nilai rata-rata 62,07, standar deviasi 10,86 nilai minimum 32 dan nilai maksimum 73, variabel ketahanan komunitas didapatkan hasil nilai rata-rata 61,36 standar deviasi 10,52 nilai minimum 33 nilai maksimum 74, variabel ketahanan keluarga nilai hasil rata-rata 61,90 standar deviasi 8,66 nilai minimum 32 dan nilai maksimum 73, variabel ketahanan Individu didapatkan hasil 60,23 standar deviasi 9,96 nilai minimum 34 dan nilai maksimum 75 . 
Gambar 1. Hasil Analisis SEM (Output uji T-Statistic)

Pada gambar 1 (Output uji T-Statistic), Setelah dilakukan bootstrapping untuk mengukur nilai $\mathrm{t}$

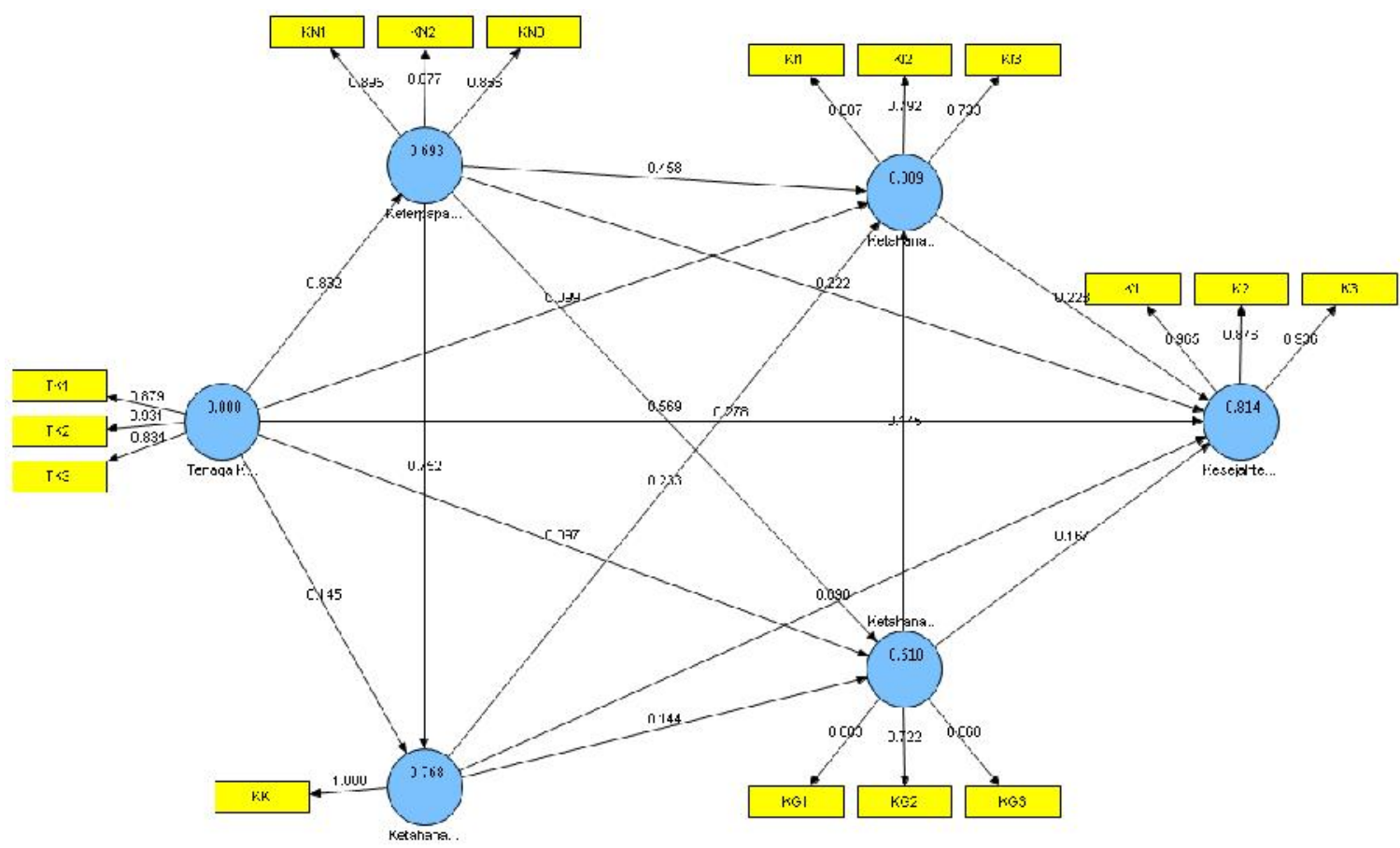

statistik dari masing-masing konstruk laten terhadap konstruknya, maka nilai t statistik dibandingkan dengan nilai $\alpha=0,05(1,96)$. Ketentuannya, apabila nilai t-statistik lebih besar dari nilai $\alpha=0,05(1,96)$, maka konstruk laten tersebut signifikan terhadap konstruknya. ${ }^{12}$ hasil pengukuran nilai t statistik dari setiap indikator ke variabel lebih besar dari 1,96 dengan tingkat kepercayaan $95 \% \quad(\alpha=0,05)$. Hal itu berarti, semua indikator berpengaruh secara signifikan terhadap variabel yang diteliti.

\section{Pengaruh Antara Peran Tenaga Kesehatan Terhadap Kesejahteraan ibu dan anak}

Pada gambar 1, menyatakan bahwa tenaga kesehatan berpengaruh positif terhadap keterpaparan informasi, hasil uji menunjukkan ada pengaruh positif 0,832400 , sedangkan nilai $\mathrm{T}$ Statistik sebesar 31,604822 dan signifikan pada $\alpha=5 \%$, nilai T-Statistik tersebut berada di atas nilai kritis $(1,96)$. Tenaga kesehatan berpengaruh positif terhadap ketahanan komunitas, hasil uji menunjukkan ada pengaruh positif 0,144816, sedangkan nilai T-Statistik sebesar 3,851977 dan signifikan pada $\alpha=5 \%$, nilai T-Statistik tersebut berada di atas nilai kritis $(1,96)$. Tenaga kesehatan berpengaruh positif terhadap ketahanan keluarga, hasil uji menunjukkan ada pengaruh positif 0,097392, sedangkan nilai T-Statistik sebesar 2,096648 dan signifikan pada $\alpha=5 \%$, nilai T-Statistik tersebut berada di atas nilai kritis $(1,96)$.

Tenaga kesehatan berpengaruh positif terhadap ketahanan individu, hasil uji menunjukkan ada pengaruh positif 0,099000, sedangkan nilai T-Statistik sebesar 2,184802 dan signifikan pada $\alpha=5 \%$, nilai T-Statistik tersebut berada di atas nilai kritis $(1,96)$. Tenaga kesehatan berpengaruh positif terhadap kesejahteraan, hasil uji menunjukkan ada pengaruh positif 0,278130 , sedangkan nilai T-Statistik sebesar 5,338840 dan signifikan pada $\alpha=5 \%$, nilai T-Statistik tersebut berada di atas nilai kritis $(1,96)$.

\section{Pengaruh Antara Keterpaparan Informasi Terhadap Kesejahteraan Ibu dan Anak}

Keterpaparan informasi berpengaruh positif terhadap ketahanan komunitas, hasil uji menunjukkan ada pengaruh positif 0,752227, sedangkan nilai T-Statistik sebesar 20,314902 dan signifikan pada $\alpha=5 \%$, nilai T-Statistik tersebut berada di atas nilai kritis $(1,96)$. Keterpaparan informasi berpengaruh positif terhadap ketahanan keluarga, hasil uji menunjukkan ada pengaruh 
positif 0,568805 , sedangkan nilai T-Statistik sebesar 8,764132 dan signifikan pada $\alpha=5 \%$, nilai TStatistik tersebut berada di atas nilai kritis $(1,96)$. Keterpaparan informasi berpengaruh positif terhadap ketahanan individu, hasil uji menunjukkan ada pengaruh positif 0,457657 , sedangkan nilai T-Statistik sebesar 10,354940 dan signifikan pada $\alpha=5 \%$, nilai T-Statistik tersebut berada di atas nilai kritis $(1,96)$.

Keterpaparan informasi berpengaruh positif terhadap kesejahteraan, hasil uji menunjukkan ada pengaruh positif 0,222373 , sedangkan nilai T-Statistik sebesar 3,124716 dan signifikan pada $\alpha=5 \%$, nilai T-Statistik tersebut berada di atas nilai kritis $(1,96)$.

\section{Pengaruh Antara Ketahanan Komunitas Terhadap Kesejahteraan Ibu dan Anak}

Ketahanan komunitas berpengaruh positif terhadap ketahanan keluarga, hasil uji menunjukkan ada pengaruh positif 0,143720, sedangkan nilai T-Statistik sebesar 2,616962 dan signifikan pada $\alpha=5 \%$, nilai T-Statistik tersebut berada di atas nilai kritis $(1,96)$.

Ketahanan komunitas berpengaruh positif terhadap ketahanan individu, hasil uji menunjukkan ada pengaruh positif 0,233314, sedangkan nilai T-Statistik sebesar 6,101445 dan signifikan pada $\alpha=5 \%$, nilai T-Statistik tersebut berada di atas nilai kritis $(1,96)$. Ketahanan komunitas berpengaruh positif terhadap kesejahteraan, hasil uji menunjukkan ada pengaruh positif 0,090137, sedangkan nilai T-Statistik sebesar 2,670062 dan signifikan pada $\alpha=5 \%$, nilai T-Statistik tersebut berada di atas nilai kritis $(1,96)$.

\section{Pengaruh Antara Ketahanan Keluarga Terhadap Kesejahteraan Ibu dan Anak}

Ketahanan keluarga berpengaruh positif terhadap ketahanan individu, hasil uji menunjukkan ada pengaruh positif 0,175467, sedangkan nilai T-Statistik sebesar 5,961694 dan signifikan pada $\alpha=5 \%$, nilai T-Statistik tersebut berada di atas nilai kritis $(1,96)$. Ketahanan keluarga berpengaruh positif terhadap kesejahteraan, hasil uji menunjukkan ada pengaruh positif 0,166838 , sedangkan nilai T-Statistik sebesar 7,635835 dan signifikan pada $\alpha=5 \%$, nilai T-Statistik tersebut berada di atas nilai kritis $(1,96)$.

\section{Pengaruh Antara Ketahanan Individu Terhadap Kesejahteraan Ibu dan Anak}

Ketahanan individu berpengaruh positif terhadap kesejahteraan, hasil uji menunjukkan ada pengaruh positif 0,228156, sedangkan nilai T-Statistik sebesar 4,599410 dan signifikan pada $\alpha=5 \%$, nilai T-Statistik tersebut berada di atas nilai kritis $(1,96)$.

\section{PEMBAHASAN}

\section{Pengaruh Antara Peran Tenaga Kesehatan Terhadap Kesejahteraan ibu dan anak}

Hasil uji terhadap koefisien parameter antara peran tenaga kesehatan dan kesejahteraan Ibu dan anak pasca melahirkan menunujukan ada pengaruh positif sebesar 0,278130, nilai Statistik sebesar 5,338840 dan signifikan pada $\alpha=5 \%$. Nilai T-Statistik tersebut berada di atas nilai kritis $(1,96)$.

Peran petugas kesehatan adalah suatu kegiatan yang diharapkan dari seorang petugas kesehatan yang memberikan pelayanan kesehatan kepada masyarakat untuk meningkatkan derajat masyarakat. ${ }^{12}$ Suatu pola tingkah laku, kepercayaan, nilai, sikap yang diharapkan oleh masyarakat muncul dan menandai sifat dan tindakan si pemegang kedudukan. Jadi peran menggambarkan perilaku yang seharusnya diperlihatkan oleh individu pemegang peran tersebut dalam situasi umum. $^{13}$

Hasil penelitian ini sejalan dengan penelitian sebelumnya yang dilakukan oleh darsono dan hasan dalam judul "peran tenaga kesehatan dan ketahanan komunitas terhadap kesejahteraan" dengan $\mathrm{p}$ value $=0,00 ; \mathrm{OR}=8,628 ; 95 \% \mathrm{CI}(1,746-15,842)$, yang menunujukkan bahwa peran tenaga kesehatan mampu membentuk kesejahteraan ibu dan anak dan dapat mengurangi AKI (Angka Kematian Ibu) dan AKB (Angka Kematian Bayi) peran tenga kesehatan sebagai motivator ini bermakna dorongan terhadap serangkaian proses perilaku manusia pada pencapaian tujuan. 
Elemen yang terkandung dalam motivasi meliputi unsur membangkitkan, mengarahkan, menjaga, menunjukkan intensitas, bersifat terus menerus dan adanya tujuan. ${ }^{14}$ Penulis menganalisis bahwa peran tenaga kesehatan tidak lepas dari faktor motivator, edukator dan fasilitator pemberi inisiatif masyarakat dalam hal kesehatan nya agar terciptanya kesejahteraan kesehatan ibu dan anak.

\section{Pengaruh Antara Keterpaparan Informasi Terhadap Kesejahteraan Ibu dan Anak}

Hasil uji terhadap koefisien parameter untuk pengaruh langsung keterpaparan informasi terhadap kesejahteraan ibu dan Anak menunjukkan terdapat pengaruh positif 0,222373 sedangkan nilai T-statistik sebesar 3,124716 dan signifikan $\alpha=5 \%$, nilai $\mathrm{T}$ statistik tersebut berada di atas nilai kritis $(1,96)$. Berdasarkan hasil uji tersebut dapat dijelaskan bahwa pengaruh langsung keterpaparan informasi lebih besar nilainya dibandingkan dengan pengaruh tidak langsung dan signifikan ada pengaruh positif dari kedua variable tersebut. Nilai T-Statistik menunjukkan bahwa ada pengaruh langsung dan tidak langsung antara keterpaparan informasi dan kesejahteraan ibu dan anak.

Informasi yang baik dan berasal berbagai sumber akan meningkatkan pengetahuan seseorang, informasi yang akan diterima merupakan suatu dasar dari meningkatnya pengetahuan seseorang, semakin banyak informasi yang didapat maka semakin tinggi pula tingkat pengetahuannya. ${ }^{15}$

Hasil penelitian ini sejalan dengan penelitian sebelumnya yang dilakukan oleh Juli Wijayanto yang berjudul "Faktor-faktor yang mempengaruhi kesejahteraan" menunjukkan ada hubungan antara keterpaparan informasi terhadap kesejahteraan ibu hamil ( $\mathrm{P}$ value) $=0,000 \mathrm{OR}$ 10,$683 ; 95 \% \mathrm{Ci}(3,438-16,419){ }^{16}$

Sehingga dengan keterpaparan informasi mempunyai pengaruh yang sangat kuat dalam pembentukkan pengetahuan seseorang, media memberikan informasi dan pengetahuan yang pada akhirnya dapat membentuk persepsi positif sehingga dapat meningkatkan kesejahteraan ibu dan anak. Penulis menganalisis bahwa peningkatan pengetahuan seseorang melalui media informasi dapat memberikan pemikiran yang positif tentang kesehatan dan sebagai promosi kesehatan dapat merubah perilaku individu, kelompok atau masyarakat demi mencapai tujuan kesejahteraan ibu dan anak.

\section{Pengaruh Antara Ketahanan Komunitas Terhadap Kesejahteraan Ibu dan Anak}

Hasil uji terhadap koefisien parameter antara ketahanan komunitas terhadap kesejahteraan ibu dan anak di wilayah Kabupaten Cirebon menunjukkan ada pengaruh positif 0,090137 sedangkan nilai T-statistik sebesar 2,670062 dan signifikan pada $\alpha=5 \%$, nilai Statistik tersebut berada diatas nilai kritis. Berdasarkan hasil uji tersebut dapat dijelaskan bahwa pengaruh langsung dan tidak langsung dan signifikan ada pengaruh yang positif dari kedua variabel tersebut. Nilai Tstatistik menunjukkan bahwa ada pengaruh langsung dan tidak langsung antar ketahanan komunitas dan kesejahteraan ibu dan anak di wilayah Kabupaten Cirebon.

Dalam membentuk ketahanan keluarga ada delapan fungsi keluarga yang harus dijalankan guna mencapai keluarga yang sejahtera antara lain fungsi agama, fungsi sosial budaya, fungsi cinta kasih, fungsi perlindungan, fungsi reproduksi, fungsi sosialisasi dan pendidikan, fungsi pemeliharaan lingkungan. Dengan tujuan untuk meningkatkan kondisi dinamis keluarga agar memiliki keuletan dan ketangguhan, kemampuan fisik- material dan mental spiritual sehingga dapat mengembangkan diri dan keluarganya sejahtera lahir dan batin. Edukasi laktasi, manfaat ASI, perawatan payudara agar kualitas ASI banyak dan anak sehat. Dengan ASI dapat mengurangi angka kematian Ibu karena dengan memberikan ASI uterus ibu akan berkontraksi dan menghentikan perdarahan post partum. ${ }^{17}$

Penelitian di India menyebutkan bahwa peran komunitas wanita dalam KIA cukup berpengaruh dalam menurunkan Angka Kematian Ibu. Peran yang dapat dilakukan oleh komunitas perempuan antara lain dalam melakukan identifikasi dan deteksi dini terkait adanya masalah dalam kehamilan hingga persalinan. Hal ini dapat menurun AKI sebesar 23\% dan Angka Kematian Anak 20\%. Penulis menganalisis bahwa ketahanan komunitas sangat berperan dalam kesejahteraan ibu 
dan anak. Komunitas dibutuhkan pelatihan dan supervisi untuk memastikan komunitas memberikan pelayanan yang berkualitas terutama KIA.

\section{Pengaruh Antara Ketahanan Keluarga Terhadap Kesejahteraan Ibu dan Anak}

Hasil uji terhadap koefisien parameter antara ketahanan keluarga berpengaruh positif terhadap kesejahteraan di wilayah Kabupaten Cirebon menunujukkan ada pengaruh positif 0,166838 , sedangkan nilai $T$-statistik sebesar 7,635835 dan signifikan pada $\alpha=5 \%$, nilai T-statistik tersebut berada di atas nilai kritis (1,96). Berdasarkan hasil uji tersebut dapat dijelaskan bahwa pengaruh langsung dan tidak langsung dan signifikan ada pengaruh yang positif dari kedua variable tersebut. Nilai T-statistik menunjukkan bahwa ada pengaruh langsung dan tidak langsung antar ketahanan keluarga dan kesejahteraan ibu dan anak di wilayah Kabupaten Cirebon.

Tiga faktor ketahanan keluarga yaitu ketahanan fisik, ketahanan sosial dan ketahanan psikologis, seiring dengan berkembangnya social kehidupan masyarakat, hal ini semakin mengokohkan peran keluarga sebagai instituisi pertama dan utama dalam pembangunan sumber daya manusia. Semua proses kehidupan utama berlangsung dalam keluarga, seberapa mampu sebuah keluarga beradaptasi dengan sosial masyarakatnya bergantung pada seberapa kuat ketahanan keluarga.

Penulis menganalisis bahwa ketahanan keluarga menjadi penting sehubungan dengan fakta adanya variasi kemampuan keluarga dalam kemampuan keluarga dalam pemenuhan kebutuhan, pelaksanaan fungsi, melalui pengelolaan sumber daya yang dimiliki, serta kemampuan dalam pengelolaan stress. Menyusun tujuan untuk meningkatkan kualitas kehidupan dan kesejahteraan ibu dan anak.

\section{Pengaruh Antara Ketahanan Individu Terhadap Kesejahteraan Ibu dan Anak}

Hasil uji terhadap koefisien parameter antara ketahanan Individu berpengaruh positif 0,228156, sedangkan nilai T-statistik sebesar sebesar 4,599410 dan signifikan pada $\alpha=5 \%$ niali Statistik tersebut berada di atas nilai kritis $(1,96)$. Berdasarkan hasil uji tersebut dapat dijelaskan bahwa pengaruh langsung dan tidak langsung dan signifikan ada pengaruh yang positif dari kedua variable tersebut. Nilai T-statistik menunjukkan bahwa ada pengaruh langsung dan tidak langsung antar ketahanan Individu dan kesejahteraan ibu dan anak di wilayah Kabupaten Cirebon.

Penelitian ini sejalan dengan penelitian sebelumnya yang dilakukan oleh Musa dengan judul "Ketahanan individu terhadap kesejahtraan Ibu dan Anak". Metode penelitian kuantitatif studi scross sectional ada hubungan antara ketahanan Individu terhadap kesejahteraan keuarga dengan $P$ Value $=0,039$ OR=3,628;95\% CI $(1,121-6,234) .{ }^{18}$

Individu adalah yang mempunyai peranan amat penting dalam mengembangkan dirinya, mencegah, beradaptasi atau memperbaiki masalah kesehatan keluarga. Masalah kesehatan anggota keluarga amat terkait dengan berbagai masalah anggota keluarga lainnya, jika ada salah satu anggota yang bermasalah kesehatannya pasti akan mempengaruhi keadaan psikis Individu itu sendiri. ${ }^{19}$ Penulis mengananlisis bahwa ketahanan individu adalah kondisi dinamis atau penampilan seseorang yang terdiri dari keuletan dan kemampuan dalam mengembangkan kekuatan diri menghadapi ancaman dan gangguan untuk mencapai kesejahteran.

\section{SIMPULAN}

Dari penelitian ini dapat ditarik kesimpulan bahwa terdapat pengaruh positif dari peran tenaga kesehatan, keterpaparan informasi, ketahanan komunitas, ketahanan keluarga, ketahanan individu terhadap kesejahteraan, semakin baik tenaga kesehatan, keterpaparan Informasi, ketahanan komunitas, ketahanan keluarga, ketahanan individu maka semakin baik kesejahteraan ibu dan anak pasca melahirkan di wilayah Kabupaten Cirebon tahun 2018.

Peran tenaga kesehatan merupakan faktor dominan yang sangat mempengaruhi kesejahteraan ibu dan anak di wilayah Kabupaten Cirebon. Semakin dekat peran tenaga kesehatan terhadap masyarakat semakin sejahtera kesehatan ibu dan anak di wilayah Kabupaten Cirebon. 
Sehingga terjalinnya hubungan yang harmonis antara tenaga kesehatan dan masyarakat mampu mengupayakan program kesehatan dan kesejahteraan ibu dan anak.

\section{SARAN}

Berdasarkan hasil penelitian ini, maka diharapkan tenaga kesehatan terus melakukan motivasi, edukasi dan fasilitator terhadap masyarakat terutama ibu hamil, nifas dan menyusui. ketahanan keluarga memiliki peran penting karena keluarga dianggap orang yang paling terdekat, apabila di keluarga memiliki kasih sayang, rasa aman dan juga memberika motivasi agar ibu dan anak pasca melahirkan menjadi sejahtera. Komunitas juga dapat meningkatkan pengetahuan nya dan banyak memperoleh informasi dengan sering diakannya pelatihan dan seminar kesehatan

\section{DAFTAR PUSTAKA}

1. Undang-Undang Nomor 52 tahun 2009 tentang pembangunan kependudukan dan pembangunan keluarga sejahtera. [Diakses tanggal 3 Oktober 2018]. Tersedia dari: https://jdih.kemenpppa.go.id/peraturan/uu\%20no\%2052\%20tahun\%202009.pdf

2. Badan Pusat Statistik. Persentase penduduk yang mempunyai keluhan kesehatan selama sebulan terakhir.[Diakses tanggal 8 Oktober 2018]. Tersedia dari: https://www.bps.go.id/dynamictable/2015/09/19\%2000:00:00/921/persentase-penduduk-yangmempunyai-keluhan-kesehatan-selama-sebulan-terakhir-menurut-provinsi-2000-2017.html

3. Ristekdikti. Undang-undang No.20 tahun 2003 tentang Sistem pendidikan Nasional. [Diakses tanggal 2 Oktober 2018]. Tersedia dari : https://kelembagaan.ristekdikti.go.id/wpontent/uploads/2016/08/UU_no_20_th_2003.pdf

4. DepKes RI. Pedoman pemantauan wilayah setempat kesehatan ibu dan anak (PWS-KIA). Jakarta: DitJen BinKesMas;2009

5. BKKBN. Keluarga berencana dan kesehatan reproduksi. Jakarta: BKKBN;2012

6. BKKBN. Program PEKKA tentang perempuan kepala rumah tangga. Jakarta: Badan Koordinasi Keluarga Berencana;2015

7. Ermawati, W. Program pelatihan bina mental spiritual dalam menumbuhkan ketahanan pribadi pemuda. Tesis. Bandung: Universitas Pendidikan Indonesia;2016

8. Nursalam. Konsep dan penerapan metodologi penelitian ilmu keperawatan. Pedoman skripsi. Jakarta: Salemba Medika;2008.

9. Anonim. Profil Dinas kesehatan Kabupaten Cirebon. Cirebon: Dinas Kesehatan;2015

10. Sunarti. Naskah akademik, indikator keluarga sejahtera. Departemen ilmu keluarga dan konsumen. Bogor: Fakultas Ekologi Manusia IPB ;2008.

11. Notoatmojo, S. Metodologi penelitian kesehatan. Jakarta: PT Rineka Cipta;2010

12. Setiadi. Manajemen mutu pelayanan kesehatan untuk bidan. Jakarta: Trans Info Media;2011

13. Handayani, Ys. Buku ajar pelayanan keluarga berencana.Yogyakarta: Pustaka Rihama;2010

14. Notoatmojo S. Promosi kesehatan teori dan aplikasi. Jakarta: PT Rineka Cipta; 2015

15. Gustira, A. Jenis-jenis media social. [Diakses tanggal 3 Oktober 2018]. Tersedia dari : https://www.kompasiana.com/alfiangustira/552bbaee6ea834f6798b456f/jenis-jenis-mediasocial

16. Wijayanto. Pengaruh enverionmental performance dan enverionmental disclosure terhadap economical performance. Prosseding. Depok: Accounting conference ;2007

17. Aliva. Model kesejahteraan ibu dalam pencapaian ASI ekslusif. Jurnal Media Kesehatan Masyarakat Indonesia.Makasar: FKM Unhas;2013

18. Musa Nurhaidah. Dampak pengaruh globalisasi bagi kehidupan bangsa Indonesia. Jurnal Pesona Dasar. Banda Aceh;Universitas Syiah Kuala;2015

19. Utami Cicilia T. Self-efficacy dan resiliensi. Sebuah tinjauan meta analisis. Buletin Psikologi. [Diakses tanggal 4 Oktober 2018]. Tersedia dari : https://jurnal.ugm.ac.id/buletinpsikologi 